\title{
O SIMULACIJI SUĐENJA (MOOT COURT NATJECANJU) KAO PRAKTIČNOM OBLIKU NASTAVE NA PRAVNIM FAKULTETIMA
}

Antonija Ivančan, mag. iur., LL.M. *

Davor Petrić, mag. iur. **
UDK: 378.4.096:34]-057.87

347.965:340.143

DOI: 10.3935/zpfz.69.2.05

Prethodno znanstveno priopćenje

Primljeno: srpanj 2018.

Moot court natjecanje jest simulacija suđenja pred arbitražnim, nacionalnim ili međunarodnim sudom koja se sve više koristi kao oblik nastave na pravnim fakultetima. U ovom radu najprije općenito razmatramo osnovne teorijske i praktične dimenzije simuliranih suđenja kao oblika nastave. Zatim na temelju kratkog, uvodnog empirijskog istraživanja usmjerenog na odvjetničku praksu provjeravamo donosi li studentima iskustvo sudjelovanja u simulacijama sudenja prednost pri zapošljavanju i u radu, odnosno profitiraju li i na koji način profitiraju studenti koji tijekom studija ulože određeno vrijeme u sudjelovanje u simuliranom suđenju. Ovaj rad također je prvi pokušaj strukturirane akademske rasprave o naravi i primjeni simulacija sudenja na našsm govornom području. Stoga je dodatni cilj rada iniciranje sireg akademskog dijaloga o korištenju te metode u obrazovanju pravnika, kao i uključivanje pravne prakse u izradu preporuka za izmjene i prilagodbe studijskih programa pravnih fakulteta u pogledu metoda praktične nastave. $U$ radu se nakon uvodnog dijela najprije prikazuje povijesni razvoj moot court natjecanja kao obrazovne metode. Nakon toga sistematiziraju se opsežni nalazi iz literature te se prikazuju konkretne prednosti i nedostaci simulacija suđenja. U završnom dijelu

\footnotetext{
Antonija Ivančan, mag. iur., LL.M., asistentica Pravnog fakulteta Sveučilišta u Zagrebu, Trg Republike Hrvatske 14, Zagreb; aivancan@pravo.hr;

ORCID ID: orcid.org/0000-0001-7192-2449

Stavovi i mišljenja izneseni u ovom radu pripadaju isključivo autorima.

** Davor Petrić, mag. iur., asistent Pravnog fakulteta Sveučilišta u Zagrebu, Trg Republike Hrvatske 14, Zagreb; dpetric@pravo.hr;

ORCID ID: orcid.org/0000-0001-7737-2150

Stavovi i mišljenja izneseni u ovom radu pripadaju isključivo autorima.
} 
rada izlažu se i tumače inicijalni rezultati anketnih upitnika poslanih odvjetničkim društvima u gradu Zagrebu. Konačno, u posljednjoj cjelini se raspravlja o zaključcima teorijskog pregleda i provedenog kratkog istraživanja.

Ključne riječi: simulacija suđenja (moot court natjecanje), praktična nastava, pravni fakultet, prednosti i nedostaci, odvjetnička društva

\section{UVODNE NAPOMENE}

Moot court natjecanje jest simulacija suđenja pred arbitražnim, nacionalnim ili međunarodnim sudom ${ }^{1}$ koja se sve više koristi kao oblik nastave na pravnim fakultetima. Zagovornici te obrazovne metode tvrde da sudjelovanje u natjecanjima simuliranog suđenja studentima donosi mnogobrojne koristi. Osnovni cilj ovog rada je, najprije, općenito razmotriti osnovne teorijske i praktične dimenzije simuliranih suđenja kao oblika nastave te zatim s pomoću kratkih anketnih upitnika provjeriti donosi li zaista takvo iskustvo prednost u praksi, odnosno profitiraju li i na koji način profitiraju (primjerice, prilikom zapošljavanja ili u budućem radu) studenti koji tijekom studija ulože određeno vrijeme u sudjelovanje na natjecanjima u simuliranom suđenju. Napominjemo odmah da u strukturi rada drugi dio, tj. provedeno pojednostavnjeno empirijsko istraživanje čini samo početnu provjeru stavova poslodavaca s idejom prikupljanja inicijalnih podataka o reakciji tržišta na uvođenje simuliranih suđenja u kurikule pravnih fakulteta. U svakom slučaju, namjera autora nije provođenje opsežnog empirijskog istraživanja, nego (primarno) teorijska rasprava o simuliranim suđenjima kao obliku nastave te (sekundarno) iznošenje inicijalnih stavova pravne prakse na temelju kojih autori testiraju pretpostavke i formuliraju zaključke o prednostima i nedostacima moot court natjecanja. Također, na ovaj se način otvara prostor drugim zainteresiranim autorima za provođenje strukturiranih i razrađenih anketa i intervjua u cilju donošenja uvjerljivijih zaključaka o problemima raspravljenim u ovom radu.

U svrhu kratkog istraživanja, čija ograničenja navodimo niže u tekstu, određenom broju odvjetničkih društava u gradu Zagrebu putem elektroničke pošte poslane su ankete iz kojih se nastojao dobiti odgovor na osnovno istraživačko pitanje: Prepoznaje li odvjetnička praksa vrijednost simulacija suđenja kao oblika izvođenja nastave, odnosno je li točna hipoteza ponuđena u literaturi da se sudjelovanje u moot court natjecanjima od strane poslodavaca smatra poželjnim, tj.

1 Napominjemo da u ovom radu koristimo uvriježeni naziv moot court natjecanje iako se u pojedinim natjecanjima kao institucije čiji se postupci simuliraju osim sudova pojavljuju i druga javna i arbitražna tijela. Zahvaljujemo jednom od anonimnih recenzenata na skretanju pozornosti na tu terminološku razliku. 
prednošću prilikom zapošljavanja? Napominjemo da je ova jednostavna anketa rađena po uzoru na ankete korištene u sličnim istraživanjima na koja se kroz citiranu literaturu pozivamo u radu. Iako metoda s određenim manjkavostima, za potrebe ovog rada smatramo je prikladnim indikatorom utemeljenosti ponuđenih zaključaka s obzirom na to da se uobičajeno koristi pri provjeri ove i sličnih pretpostavki od strane inozemnih autora koji se bave istom tematikom.

Dosadašnje iskustvo autora, kao sudionika na pojedinim moot court natjecanjima te voditelja studentskih moot court timova, sugerira da pojedina odvjetnička društva i poduzeća običavaju izravno kontaktirati profesore ili fakultetske katedre tražeći od njih da preporuče - za zaposlenje ili pripravništvo - studente koji su sudjelovali na moot court natjecanjima, smatrajući takvo iskustvo poželjnom karakteristikom i prednošću u odnosu na ostale kandidate, odnosno studente.

Jedan od ciljeva ovog rada je i iniciranje akademskog dijaloga o korištenju te metode $\mathrm{u}$ obrazovanju pravnika, kao i uključivanje pravne prakse $\mathrm{u}$ izradu preporuka za izmjene i prilagodbe studijskih programa pravnih fakulteta u pogledu metoda praktične nastave. Navedena tema - utjecaj praktičnih metoda nastave na transformaciju pravničkog obrazovanja u Europi - trenutačno je jedna od najaktualnijih u području metodologije prava. ${ }^{2}$

Rad, koji je ujedno prvi pokušaj strukturirane akademske rasprave o naravi i primjeni simulacija suđenja na našem govornom području (navedenu, potencijalno preuzetnu tvrdnju temeljimo na iscrpnoj pretrazi relevantnih baza znanstvenih radova, primjerice HeinOnline, EBSCO i Hrčak, u kojima nismo pronašli radove na hrvatskom, bosanskom, srpskom ili crnogorskome jeziku koji se bave moot court natjecanjima) sastoji se od sljedećih cjelina: nakon uvoda (dio 1.) slijedi povijesni pregled razvoja moot court natjecanja kao metode obrazovanja pravnika (dio 2.). Nakon toga u glavnoj cjelini rada (dio 3.) sistematiziraju se nalazi iz literature te se prikazuju konkretne prednosti i nedostaci simulacija suđenja. Zatim (dio 4.) izlažu se i tumače rezultati upitnika. U posljednjoj cjelini (dio 5.) raspravlja se o zaključcima teorijskog pregleda i provedenog kratkog istraživanja.

U pogledu ograničenja ovog istraživanja ističemo da usmjeravamo pozornost na samo jednu metodu praktične nastave (simulacije suđenja) koja se izvodi na pravnim fakultetima te ne raspravljamo o nizu drugih metoda (primjerice: pravne klinike, debate, simulacije donošenja odluka u nacionalnim i međunarodnim institucijama itd.) koje imaju za cilj unaprjeđenje pravničkih i generičkih

2 Vidi, primjerice, Alemanno, A.; Khadar, L., Reinventing Legal Education. How Clinical Education Is Reforming the Teaching and Practice of Law, Cambridge University Press, Cambridge, 2018. 
vještina studenata. Također, usmjeravanjem pozornosti na simulacije suđenja u prvi plan stavlja se odvjetnička profesija, čime se, iako je vjerojatno riječ o dominantnom području zapošljavanja studenata prava nakon diplomiranja, zanemaruju ostale dimenzije pravnog obrazovanja i profesije kao što su rad u državnim institucijama, rad u nevladinu sektoru, ostali pravni poslovi koji se primarno ne odnose na zastupanje pred sudovima itd. Istodobno, odvjetnička profesija odabrana je s pretpostavkom da se upravo odvjetnici najčešće susreću s poslovima zastupanja pred sudovima, što nam se čini najrelevantnijim iz perspektive rasprave o simulacijama suđenja kao nastavnoj metodi. Nadalje, naše istraživanje ograničeno je zemljopisno s obzirom na to da se odnosi na Pravni fakultet u Zagrebu, najveći pravni fakultet u Republici Hrvatskoj te jedan od najprestižnijih pravnih fakulteta $\mathrm{u}$ regiji, $\mathrm{s}$ čijim smo nastavnim programom $\mathrm{i}$ praktičnim metodama nastave najbolje upoznati. Pristup raspravi dijelom je određen pozitivnim iskustvom autora $\mathrm{u}$ korištenju simulacija suđenja u izvođenju nastave. Također, kratki upitnik usmjerili smo na odvjetnička društva s područja grada Zagreba, koja su također vodeća društva u Republici Hrvatskoj, a među njima su i međunarodna/regionalna odvjetnička društva koja djeluju na području jugoistočne Europe (potpuni popis anketiranih odvjetničkih društava i ureda, zajedno s primjerom anketnih pitanja i objašnjenjem pojedinih kategorija i tipova pitanja, nalaze se $\mathrm{u}$ aneksu ovog rada). Kao što navodimo $\mathrm{u}$ aneksu, kontaktirana odvjetnička društva i uredi nasumično su odabirani s obzirom na dostupnost njihovih kontaktnih podataka u Imeniku odvjetnika Hrvatske odvjetničke komore. Nasumičnim odabirom nastojali smo barem djelomično otkloniti pristranost. Navedeni pristup također se pokazao pogodnim za potrebe ograničenog istraživanja s obzirom na (ne)izvedivost anketiranja nekoliko tisuća subjekata registriranih u spomenutom Imeniku. Činjenica da u konačnici ispitanike u velikoj većini čine odvjetnička društva povezana je s pretpostavkom (utemeljenom na iskustvima iz prakse) da su upravo odvjetnička društva poslodavci koji u skladu s dostupnim sredstvima i kapacitetima (u pogledu menadžmenta ljudskih resursa te upravljanja kadrovima) najčešće provode (u prosjeku) opsežnije selekcijske procese u usporedbi sa samostalnim odvjetničkim uredima; imaju veći kontakt sa studentima Pravnog fakulteta koji kod njih obavljaju obveznu praksu te potencijalno imaju najveći "protok" odvjetničkih vježbenika. Konačno, sužavanje analize na područje grada Zagreba činilo nam se logičnim s obzirom na raspravu o simulacijama suđenja u nastavnom programu Pravnog fakulteta u Zagrebu; također i zbog koncentracije odvjetničkih društava, sjedišta trgovačkih društava te viših sudova u glavnom gradu Republike Hrvatske.

Dodatno ograničenje istraživanja jest vjerojatnost da će na upitnike imati poticaj odgovarati odvjetnička društva i uredi koji zapošljavaju ili imaju kontakt 
s osobama koje su sudjelovale na moot court natjecanjima, te su stoga upoznati s koristima tih natjecanja u radu u praksi, zbog čega može doći do nerazmjerno više pozitivnih odgovora o prednostima ove nastavne metode. Također, treba napomenuti da postoji mogućnost da je na upitnik odgovorilo više zaposlenih iz istog odvjetničkog društva, iako je svakom odvjetničkom društvu elektroničkom poštom poslan samo jedan upit, što nije moguće provjeriti s obzirom na to da su upitnici anonimni. Premda je vjerojatnost za to mala, u tom slučaju pristranost bi odgovora bila dodatno povećana.

\section{POJAM I RAZVOJ}

Pojam moot u pravu se pojavljuje sredinom 16. stoljeća, točnije 1531. godine, kada je na engleskom govornom području zabilježeno prvo korištenje te riječi. ${ }^{3}$ Originalno je taj pojam označavao 'formaliziranu pravnu raspravu', odnosno hipotetski predmet o kojem su za potrebe vježbe raspravljali studenti prava. Stoga, pojam moot problem označava i pitanje koje je otvoreno za raspravu ili debatu. ${ }^{5}$ Međutim, zbog hipotetske naravi predmeta o kojem se raspravljalo, sredinom 19. stoljeća pojam moot u engleskom jeziku počinje dobivati značenje bliže pojmu beznačajno ili irelevantno. ${ }^{6} \mathrm{U}$ ovom kontekstu moot problem, iako posjeduje diskurzivnu vrijednost, nema nikakvu praktičnu vrijednost. Zbog toga je važno na samom početku spomenuti etimološku razliku između tih dvaju značenja pojma moot.

Danas je prvo navedeno značenje riječi moot, te od njega izvedenoga glagola mooting, univerzalno prepoznatljivo, i to ne samo na engleskom jeziku. Imenica moot tako označava proces rasprave o pravnom pitanju koje se pojavljuje u hipotetskom slučaju koji se izlaže pred simuliranim sudom. ${ }^{7}$ Glagol mooting označava proces sudjelovanja u mootu u jednoj od niže navedenih uloga. Sudionici u mootu nazivaju se mooters ili mooties (kod nas se pojavljuje i pojam mootovci), te u pravilu zauzimaju pozicije tužitelja i tuženika (u različitim natjecanjima pojavljuju se

3 Snape, J.; Watt, G., How to Moot - A Student Guide to Mooting (2 ${ }^{\text {nd }}$ Edition), Oxford University Press, Oxford, 2010., str. 6; Snape, J.; Watt, G., The Cavendish Guide To Mooting (2nd Edition), Cavendish Publishing, London/Sydney, 2000., str. 4; vidi i definiciju pojma moot na Oxford English Dictionaries (en.oxforddictionaries.com/definition/moot).

4 Snape i Watt, op. cit. u bilj. 3, 2010., str. 6.

5 Ibid.

6 Ibid.

7 Snape i Watt, op. cit. u bilj. 3, 2010., str. 3; Snape i Watt, op. cit. u bilj. 3, 2000., str. 1. 
engleski nazivi stranaka u postupku - applicant, claimant, plaintiff, petitioner s jedne strane te respondent, defendant s druge). ${ }^{8}$ Uloga moot sudaca ili arbitara obično je rezervirana za različite pravne stručnjake: fakultetske profesore, odvjetnike, pa čak i prave suce. ${ }^{9}$ Nakon završetka moot court natjecanja suci donose kratku presudu u kojoj meritorno odlučuju o postavljenom pravnom pitanju, kao i o pobjedničkom timu. Stoga, za pobjedu u moot court natjecanju nisu presudni samo i isključivo pravni argumenti, nego jednako tako i prezentacija tih argumenata te osobne vještine zastupnika koji nastoje uvjeriti suce u valjanost vlastitih pravnih argumenata. ${ }^{10}$

Korištenje moota kao važne metode obrazovanja pravnika pojavljuje se u počecima funkcioniranja britanskih profesionalnih udruženja odvjetnika i pravnih zastupnika (tzv. Inns of Court i Inns of Chancery) u 16. stoljeću. ${ }^{11}$ Prema tome, moot $\mathrm{u}$ britanskom pravnom sustavu ima tradiciju dugu pet stoljeća, iako pojedini izvori upućuju na to da bi ta praksa mogla biti još i starija. ${ }^{12}$ U svakom slučaju, u navedenom razdoblju moot dobiva središnju ulogu u pravničkom obrazovanju. Takav status je naknadno bio dodatno učvršćen zbog nerasprostranjenosti tiskarskih strojeva te nedostupnosti pisanih obrazovnih materijala u većim količinama. ${ }^{13} \mathrm{U}$ nastavnom procesu moot je bio kombiniran s klasičnim predavanjima (readings) i raspravama. ${ }^{14}$ Stoga su usmena izlaganja vrhunskih pravnika u okviru tih predavanja i rasprava postala gotovo jednako utjecajna na razvoj prava kao i presude britanskih common law sudova. ${ }^{15}$ Nije bilo neobično ni da su se, zbog tradicije i važnosti usmenih izlaganja u obrazovanju pravnika, pravni argumenti iz moot slučajeva citirali pred britanskim sudovima u stvarnim slučajevima. ${ }^{16}$

Promatrano iz današnje perspektive, početno razdoblje procvata moota ostalo je i vrhunac primjene te metode $\mathrm{u}$ obrazovanju pravnika. ${ }^{17} \mathrm{~S}$ vremenom

8 Snape i Watt, op. cit. u bilj. 3, 2000., str. 4. U moot court natjecanjima iz prava Europske unije simulirane uloge mogu još biti i, primjerice, zastupnik Europske komisije ili nezavisni odvjetnik pri Sudu Europske unije.

9 Ibid., str. 1.

10 Ibid., str. 3.

11 Ibid., str. vi.

12 Ibid., str. $7-8$.

13 Snape i Watt, op. cit. u bilj. 3, 2010., str. 10.

14 Ibid.

15 Ibid.

16 Ibid., str. 11.

17 Ibid., str. 12. 
su pisani materijali postajali dostupniji te su se školovanje pravnika i pravna znanost počinjali usmjeravati više na proučavanje pisanih izvora prava nauštrb praktičnog obrazovanja te usmenih vježbi kao što je moot. ${ }^{18}$ Stoga je kroz 17. i 18. stoljeće moot polako gubio na važnosti u pravnom obrazovanju. Tek krajem 19. stoljeća moot kao metoda počinje vraćati status koji je originalno uživao. ${ }^{19}$ U tom razdoblju osnivaju se prva moot društva te se u dvadesetim godinama 20. stoljeća ponovno počinju organizirati službena moot natjecanja u britanskim udruženjima odvjetnika. ${ }^{20}$

U 21. stoljeću, kada je moot court neizostavan dio studijskih programa mnogih pravnih fakulteta, i to ne samo u anglo-saksonskoj pravnoj kulturi, može se tvrditi da moot court natjecanja imaju važnost kakvu su uživala u svojim počecima. ${ }^{21}$ Povratak moot courta na pravne fakultete diljem svijeta pripisuje se "ponovnom otkrivanju drevnih, dragocjenih metoda pravničkog obrazovanja". ${ }^{22}$ Paralelno s napretkom tehnologije povećavaju se prilike za sudjelovanje u moot court natjecanjima te se razvija elektroničko moot court natjecanje na pravnim fakultetima. ${ }^{23}$ Danas su moot court natjecanja jedno od rijetkih mjesta koja omogućavaju "konstruktivnu interakciju pravne prakse (odvjetnika i sudaca) s jedne, te profesora i studenata prava s druge strane". ${ }^{24}$ Održavanje navedene interakcije ima važnu ulogu u unaprjeđenju kompetencija uključenih dionika, kao i pojedinih elemenata pravnog sustava: od primjene prava u praksi do istraživanja i podučavanja o pravu.

Kao važna metoda obrazovanja pravnika, inicijalno korištena isključivo u anglo-saksonskim pravnim sustavima, danas su moot court natjecanja raspro-

18 Ibid., str. 10.

19 Ibid.

20 Ibid., str. 14.

21 Ibid.

22 Ibid.

23 Yule, J. M.; McNamara, J.; Thomas, M. N., Virtual mooting: using technology to enhance the mooting experience, Journal of the Australasian Law Teachers Association, sv. 2, br. 1-2, 2009., str. 235 - 237. Autori navode da sva 32 australska pravna fakulteta koriste moot court natjecanja kao obvezan oblik nastave, a najmanje ih je devet u potpunosti osuvremenilo korištenjem modernih informacijskih i komunikacijskih tehnologija kao što su video pozivi, snimanje, audio-vizualna pomagala, elektronički sustav pohrane dokumenata te interaktivne elektroničke ("pametne") ploče. Tehnološki napredak također je rezultirao međunarodnim virtualnim moot court natjecanjem (International Virtual Moot - IVM), koje od 2006. godine organizira Sveučilište Murdoch. U njemu sudjeluju timovi iz cijelog svijeta te se s pomoću interneta i modernih komunikacijskih tehnologija u potpunosti odvija u virtualnom prostoru. 
stranjena po cijelom svijetu te počinju zauzimati važno mjesto u studijskim programima pravnih fakulteta i u državama kontinentalnopravne tradicije, kao što je npr. Francuska. ${ }^{25} \mathrm{Na}$ taj trend, barem što se tiče zapadnoeuropskih zemalja, snažno je utjecao razvoj novog pravnog sustava Europske unije (izvorno Europskih zajednica, dalje u tekstu EU), čije se materijalno i proceduralno pravo sastoji od kombinacije klasičnih europskih pravnih kultura (njemačke, francuske, britanske, skandinavske itd.). U pravu EU-a moot court natjecanja su se od samih početaka koristila i kao sredstvo promoviranja i učenja o tom pravnom sustavu.

Moot court natjecanja međunarodne tematike također imaju važnu ulogu u procesu međusobnog prožimanja različitih pravnih sustava i kultura, što je od posebne važnosti u razdoblju globalizacije prava. Konkretno, u Republici Hrvatskoj, donedavno (ili još uvijek?) državi u demokratskoj tranziciji, pod utjecajem procesa "europeizacije" pravnog sustava dolazi do postupne transformacije dominantne pravne kulture, čije su karakteristike (među ostalima) kruti formalizam i pozitivizam. ${ }^{26} \mathrm{U}$ takvom sustavu pravno obrazovanje tradicionalno

25 Ibid., str. vii.

26 Opširnije o toj temi vidi u: Rodin, S., Discourse and Authority in European and Post-Communist Legal Culture, Croatian Yearbook of European Law and Policy, sv. 1, 2005., str. 1 - 22; Ćapeta, T., Courts, Legal Culture and EU Enlargement, Croatian Yearbook of European Law and Policy, sv. 1, 2005., str. 23 - 53. Također vidi: Uzelac, A., Survival of the Third Legal Tradition?, Supreme Court Law Review, sv. 49, 2010., str. 377 - 396, koji govori o socijalističkoj pravnoj tradiciji, još uvijek snažno prisutnoj u Republici Hrvatskoj (kao i ostalim državama srednje i istočne Europe) i otpornoj na demokratske promjene, čije glavne karakteristike uključuju: instrumentalizaciju prava u svrhu postizanja ciljeva ekonomske i socijalne politike; otvoreno naglašenu ideološku pozadinu pravnog sustava te služenje prava interesima vladajuće političke elite; podređenost sudstva zakonodavcu u skladu s političkom doktrinom unitarne državne vlasti, neuključivanje sudova u odlučivanje o važnim društvenim pitanjima koja ostaju rezervirana za vrh komunističke partije te posljedično prevladavanje efemernih i društveno nevažnih sudskih odluka; proceduralne manjkavosti sudskog postupka (koje su sudovi iskorištavali za beskonačne odgode donošenja konačnih odluka), pretjerani formalizam, usmjerenost sudaca na činjenična umjesto pravna pitanja, impersonalan i anoniman žalbeni postupak te usmena izlaganja pred sudom kao čista formalnost. Budući da je posljednja navedena karakteristika, uz formalizam i dominaciju činjeničnih umjesto pravnih pitanja, najvažnija za raspravu o utjecaju moot court natjecanja na prevladavajuću pravnu kulturu u Hrvatskoj, te posebno o moot court natjecanju kao metodi razvoja govorničkih vještina važnih za budući rad u odvjetničkoj profesiji, izdvajamo sljedeći dio iz rada profesora Uzelca (str. 391): "Na ročištima započinjanje usmene rasprave smatralo se nepristojnim [...] U većini slučajeva stranke bi izgovorile jedva nekoliko riječi tijekom ročišta i sva interakcija između njih i suda svela bi se na sučevo diktiranje zapisnika sudskom daktilografu. Stoga je većina odvjetnika smatrala (i dalje smatra) da je pojavljivanje 
je obilježeno metodološkim formalizmom, doktrinarnim i hijerarhijskim shvaćanjem prava te studentima kao pasivnim primateljima pravnih istina čija je glavna vještina sposobnost njihova repetitivnog korištenja. ${ }^{27}$ Razlog doprinosa moot court natjecanja procesu dalekosežne transformacije nacionalnih pravnih kultura je činjenica da se tom metodom u pravilu simuliraju postupci pred (naj) višim sudskim instancama, gdje se primjenjuju "politički" ("policy") argumenti i kritički raspravlja o pozitivnom pravu u svjetlu promjenljive društveno-političke zbilje. ${ }^{28}$ Takav pristup sudovanju još je "stran" prevladavajućoj pravnoj kulturi u Republici Hrvatskoj, prema kojoj se i dalje smatra da je pravo zatvoren sustav objektivnih normi koje se primjenjuju mehanički, izoliran od političke dinamike, te gdje se dominantno primjenjuje gramatičko tumačenje normi, a s druge strane smatra da ustavne norme nisu izravno primjenljive u postupcima pred redovnim sudovima i sl. ${ }^{29}$

\section{PREDNOSTI I NEDOSTACI}

O moot court natjecanju kao edukacijskoj metodi detaljno se raspravljalo u (gotovo u pravilu) anglo-saksonskoj literaturi o pravnom obrazovanju. Prije nekoliko desetljeća nastalo je mnoštvo knjiga i akademskih članaka posvećenih moot courtu koji su objavljivani u prestižnim pravnim časopisima. Neki od tih najvažnijih izvora na više se mjesta citiraju u ovom radu. Općenito, raspravljajući o prednostima ovog modela praktične nastave te vještinama primjenljivim na buduću pravničku karijeru, literatura je gotovo jednoglasna u pitanju koristi moot court natjecanja: neke od brojnih uočenih prednosti tog oblika nastave sistematizirane su kako slijedi.

na ročištima uživo pred sudom gubitak vremena. [...] Odvjetnički uredi na rasprave su obično slali najmlađe odvjetnike [ili vježbenike] (koji bi u pravilu znali malo ili nimalo o predmetu u pitanju). Za odvjetnike koji nisu bili u mogućnosti priuštiti si luksuz zapošljavanja vježbenika, ili koji su istodobno imali previše ročišta, sasvim normalna i uobičajena praksa bila je pojaviti se na ročištu samo kako bi ljubazno zamolili suca da zabilježi njihovu prisutnost u zapisnik te zatim zatražili dozvolu za odlazak kako bi stigli na drugu raspravu (ili nekoliko njih) zakazanu na istom sudu u isto vrijeme. Navedena praksa i dalje je raširena u većini hrvatskih sudova" (prijevod autora). Slično o europskom pristupu pravnom obrazovanju i pravnoj znanosti vidi u: Alemanno i Khadar, op. cit. u bilj. 2. 


\subsection{Koristi}

Često se pretpostavlja se da je moot court najuspješniji način savladavanja određenog područja prava, materijalnog i procesnog. Također se smatra da moot court unaprjeđuje proces učenja kroz "aktivnu interakciju studenata s pravnim pravilima”: kritičkim promišljanjem pravnih problema, logičkom analizom primjenljivog prava te osmišljavanjem i strukturiranjem argumenata. ${ }^{30}$ Studenti doživljavaju pravu ulogu pravnih zastupnika: savladavaju tehnike pronalaska i metode tumačenja pravnih pravila, primjenjuju apstraktna načela na činjenično stanje $^{31}$ te kreiraju, prezentiraju i brane kompleksne pravne argumente. ${ }^{32}$ Pope i Hill tako smatraju da moot court natjecanja u okviru školovanja dovode studente prvi put u praktičnu, stvarnu životnu situaciju, te od njih zahtijevaju da "razmišljaju kao odvjetnici/zastupnici". ${ }^{33}$ Snape i Watt $s$ druge strane naglašavaju da moot court natjecanje kao "visoko strukturirani dijalog" osposobljava studente da "objasne vrlo kompleksne pravne probleme i pravne izvore na jednostavan i jasan način" ${ }^{34}$ Kee smatra da za studenta prava "ne postoji važnija vještina od formulacije logičkog i uvjerljivog [napisanog i izgovorenog] argumenta". ${ }^{35}$ Finneran kao jednu od najvažnijih vještina koje studenti stječu moot courtom navodi strateško razmišljanje. ${ }^{36}$ Nasuprot podučavanju o prepoznavanju i apstraktnoj primjeni pravnih pravila, kakvo se nudi u sklopu "klasičnih" pravnih predmeta, moot court natjecanje studentima otkriva načine donošenja strateških odluka u konkretnim slučajevima: na koje se pravne argumente (od mnoštva) pozvati i u kojem trenutku; kojim redoslijedom izložiti argumente pred sudom u svrhu maksimiziranja šansi za uspjehom u sudskom procesu itd. ${ }^{37}$

Dakle, može se reći da moot court natjecanja razvijaju dvije vrste vještina: praktične, primjenljive u specifičnom, tj. pravničkom okruženju, te generičke,

30 Yule, McNamara i Thomas, op. cit. u bilj. 23, str. 231.

31 Knerr, C.; Sommerman, A., Undergraduate Moot Court in American Colleges and Universities, Annual General Meeting of the National Communications Association, Seattle, WA (8-12 November 2000), https://eric.ed.gov/?id=ED449747 (24. listopada 2017.).

32 Yule, McNamara i Thomas, op. cit. u bilj. 23, str. $232-233$.

33 Pope, D.; Hill, D., Mooting and Advocacy Skills (3rd Edition), Sweet \& Maxwell, London, 2015., str. $4-5$.

34 Snape i Watt, op. cit. u bilj. 3, 2010., str. 14 - 15.

35 Kee, C., A Guide to Mooting. The Art of Argument, Cambridge University Press, Cambridge, 2006., str. 2.

36 Finneran, R. E., Wherefore Moot Court?, Washington University Journal of Law \& Policy, sv. 53, 2017., str. $121-134$.

37 Ibid., str. 126. 
univerzalno primjenljive vještine. Od praktičnih vještina ističu se: kritičko razmišljanje o pravu, kroz sagledavanje pravnih pravila i činjeničnih problema iz različitih perspektiva; uvjerljivo zastupanje dodijeljene pozicije, kroz zauzimanje uloga obiju strana u sporu, čime se gradi stav o nepostojanju unaprijed izgubljenih slučajeva, te uspješno zastupanje i onih klijenata koji nemaju "povoljnu" početnu poziciju u pravnom sporu; pravna analiza i istraživanje te strukturirana, argumentirana i stilski dotjerana konstrukcija različitih tekstova (dopisi, podnesci itd.) uz citiranje pravnih izvora (posebno sudskih presuda). ${ }^{38}$

Analitičke i istraživačke vještine te vještine pisanog izražavanja usvojene $\mathrm{u}$ pravnom kontekstu povezane su s univerzalnim vještinama, primjenljivima na brojne druge aktivnosti, čak i fakultetima različitim od pravnog: primjerice, na pisane i usmene ispite ili pisanje eseja i radova. Stoga su neke od generičkih vještina koje se razvijaju moot courtom: kreativnost, samopouzdanje, liderstvo, samodisciplina i radne navike, organizacija, izgradnja osobnosti kroz preispitivanje vlastitih stavova, spoznaja vlastitih interesa i vještina, timski rad i s njim povezane vještine (kao npr. brainstorming i "grupna mudrost", rasprava, kooperativno razmišljanje i djelovanje, konzultiranje, podjela poslova i koordiniranje različitih uloga u zajedničkom projektu, upravljanje [osobnim i profesionalnim] krizama, izgradnja povjerenja itd. ${ }^{39}$, engleski jezik ${ }^{40}$, komunikacija ${ }^{41}$, javni govor (improvizacija i

38 Vidi sistematizaciju koristi moot court natjecanja i u: Snape i Watt, op. cit. u bilj. 3, 2010., str. 3 - 20; Kee, op. cit. u bilj. 35, str. 1 - 7; Gygar, T.; Cassimatis, A., Mooting Manual, Butterworths, Sydney, 1997., str. 155 - 158.

39 Funkcioniranje u timu često je raspravljana tema u literaturi koja se bavi elementima moot court natjecanja. Tvrdi se da se tim oblikom nastave na najuvjerljiviji način simuliraju uvjeti rada u odvjetničkim uredima: studenti stječu iskustvo rada u okruženju i s ljudima koje nisu birali te u uvjetima na koje ne mogu izravno utjecati. Pojedina istraživanja pokazuju da poslodavci posebno vrednuju upravo tu vrstu sposobnosti. O tome vidi više u: Kee, op. cit. u bilj. 35, str. 5 - 6. Takav pristup grupnom radu i suradničkom učenju u potpunosti je drukčiji kod ostalih, tradicionalnih metoda podučavanja na pravnim fakultetima danas. Njihov fokus je još uvijek primarno na individualnim postignućima, zbog čega se studenti najčešće dovode u poziciju međusobnog natjecanja za ocjene i pažnju profesora. Stoga nije neobično da su najbolji studenti istodobno i najlošiji timski igrači, iako je timski rad ključna komponentna uspješnog funkcioniranja društava, poduzeća i projekata. Prema tomu, njegovanje timskog rada i međusobnog pomaganja u ostvarenju zajedničkog cilja jedinstven je element koji se, za razliku od drugih nastavnih metoda, kroz moot court natjecanje prenosi studentima na fakultetima. O tome detaljno u: Finneran, op. cit. u bilj. 36, str. 127.

Međunarodna moot court natjecanja u pravilu se održavaju na engleskom jeziku. 
snalažljivost kod odgovaranja na upite sudaca te na protuargumente protivničke strane, prilagođavanje usmenog izlaganja vremenskom ograničenju), javni nastup i prezentacijske vještine (ton, glasnoća, dikcija, ritam govora, govor tijela i neverbalna komunikacija itd.). ${ }^{42}$ Sve te vrste vještina nadilaze pravni kontekst te su primjenljive na brojne druge aspekte društvenog života (npr. u međuljudskim odnosima) i profesionalnog djelovanja. Tako je moot court natjecanje kao oblik nastave koji potiče aktivno učenje i kritičko razmišljanje prepoznat i izvan pravne discipline: Carlson i Skaggs zaključuju da je taj oblik nastave primjenljiv i na studente ekonomije jer potiče njihov interes za učenjem i sudjelovanjem u nastavi. ${ }^{43}$

Postoje autori koji su promatrali socio-političke dimenzije moot court natjecanja kao nastavne metode. Gygar i Cassimatis navode njegovu ulogu u promicanju rodne ravnopravnosti i društvene jednakosti. ${ }^{44}$ Tako, primjerice, iskustvo sudjelovanja na moot court natjecanjima studentima u nepovlaštenom položaju, koji su prethodno imali problema sa sudjelovanjem u nastavi i izražavanjem vlastitih stavova i mišljenja, daje samopouzdanje i povećava aktivnost u različitim akademskim okruženjima i društvenim grupama. ${ }^{45} \mathrm{U}$ međunarodnim inačicama tog oblika pravnog obrazovanja Kee također prepoznaje višu svrhu: kultiviranje rješavanja sporova na miran, nenasilan, prijateljski i razuman način kao vrijednost koju je nužno razvijati kod novih generacija. ${ }^{46}$

Istraživanja pokazuju da studenti, bez obzira na to jesu li imali iskustvo sudjelovanja u moot court natjecanju ili nisu, smatraju da sudjelovanje u takvom natjecanju donosi brojne koristi. ${ }^{47}$ Prednosti moot court natjecanja koje pritom studenti identificiraju u velikoj mjeri koincidiraju s onima koje nudi prethodno prikazana literatura, kao što su unaprjeđenje kritičkog mišljenja, pravničke argumentacije, timskog rada, vještine javnog govora itd. ${ }^{48}$ Od ostalih razloga koje studenti najčešće navode u prilog sudjelovanju u simulacijama suđenja izdvajaju

42 Snape i Watt, op. cit. u bilj. 3, 2010., str. 3 - 20; Kee, op. cit. u bilj. 35, str. 1 - 7; Gygar i Cassimatis, op. cit. u bilj. 38, str. 155 - 158.

43 Carlson, J. L.; Skaggs, N. T., Learning by Trial and Error: A Case for Moot Courts, Journal of Economic Education, sv. 31, br. 2, 2000., str. 153.

44 Gygar i Cassimatis, op. cit. u bilj. 38, str. 156.

45 Ibid.

46 Kee, op. cit. u bilj. 35, str. 2.

47 Yule, McNamara i Thomas, op. cit. u bilj. 23, str. 238.

48 Kammerer, E. F., Undergraduate Moot Court: Student Expectations and Perspectives, PS: Political Science and Politics, sv. 51, br. 1, 2018., str. 190 - 193; također, Daly, Y. M.; Higgins, N., The Place and Efficacy of Simulations in Legal Education: A Preliminary Examination, AISHE-J: The All Ireland Journal of Teaching and Learning in Higher Education, sv. 3, br. 2, 2011., str. 58.10 - 58.13. 
se: prilika za putovanje, upoznavanje novih ljudi i kultura te zabavu (unatoč napornom radu i potencijalnim poteškoćama i izazovima s kojima se susreću), unaprjeđenje tehnika učenja primjenljivih u drugim nastavnim aktivnostima te kontekstualizacija i jasnije sagledavanje usvojene pravne građe. ${ }^{49}$ Studenti također kao poticaj za sudjelovanje u moot court natjecanju navode ostvarivanje kontakata u pravnom svijetu te razvoj profesionalnih mreža (tzv. networking), unaprjeđenje životopisa i veće prilike za zaposlenje na temelju tog iskustva. ${ }^{50} \mathrm{KaO}$ otežavajuće okolnosti, koje sprječavaju studente u sudjelovanju u natjecanjima simulacije suđenja, navedena istraživanja navode nedostatak vremena, samopouzdanja, iskustva i prethodnog znanja (pogotovo kod studenata nižih godina). ${ }^{51}$

S druge strane, mnoga istraživanja također pokazuju pozitivne stavove nastavnika i profesora o moot court natjecanjima. Većina anketiranih britanskih profesora prava u pravilu se izjašnjavala da bi simulacije suđenja trebale biti barem izborni (ako ne i obvezni) predmeti, koji ulaze u ukupan obujam studentskog opterećenja (u našem kontekstu, ECTS bodovi) na osnovi kojeg se dodjeljuje diploma prava. ${ }^{52}$ Rezultati pojedinih istraživanja upućuju na to da i pravna struka $\mathrm{u}$ Engleskoj u velikoj većini pozitivno gleda na koristi moot court natjecanja za buduće odvjetnike i pravnike. ${ }^{53}$ Više o tome bit će rečeno u poglavlju 4.

\subsection{Kritika}

Od samo nekoliko kritika moot court natjecanja kao nastavne metode na pravnim fakultetima, najpoznatija i najsofisticiranija izložena je u članku suca federalnog žalbenog suda SAD-a Alexa Kozinskog. ${ }^{54}$

49 Yule, McNamara i Thomas, op. cit. u bilj. 23, str. 239.

50 Pope i Hill, op. cit. u bilj. 33, str. 6.

51 Yule, McNamara i Thomas, op. cit. u bilj. 23, str. 240.

52 Bright, S., What, and how, should we be teaching?, Law Teacher, sv. 25, br. 1, 1991., str. 18, navedeno prema Snape i Watt, op. cit. u bilj. 3, 2000., str. 14.

53 Calder, K.; Sacranie, S., Is mooting useful in degree level education, and if so, how should it be integrated into a degree programme?, Unpublished LLB dissertation, University of Warwick, 1996., navedeno prema Snape i Watt, op. cit. u bilj. 3, 2010., str. 16.

54 Kozinski, A., In Praise of Moot Court - Not!, Columbia Law Review, sv. 97, br. 1, 1997. str. 178 - 197. Njegova kritika odnosi se na moot court natjecanja na američkim pravnim fakultetima, ali smatramo da su argumenti univerzalno primjenljivi. Također, vrijedi napomenuti da kritičari nisu a priori protiv simulacija suđenja. Prve kritike pojavile su se u literaturi desetljećima nakon uvođenja moot court natjecanja u nastavne programe sveučilišta u SAD-u i većinom su usmjerene na određene finese, kao što je (ne)realnost pravnog okruženja kakvo se simulira u takvim natjecanjima. 
Da bismo objasnili ključne argumente kritike moot court natjecanja, potrebno je najprije utvrditi njegovo razlikovanje od druge forme simuliranog suđenja, tzv. mock triala. Osnovna razlika je u vrsti suda pred kojim se simulira suđenje: u prvom slučaju riječ je o višim instancama, tj. žalbenim ili ustavnim sudovima, a u drugom o nižim instancama, tj. prvostupanjskim, raspravnim/građanskim sudovima. ${ }^{55}$ Drugim riječima, moot court simulira sporove o pravu, a mock trial sporove o činjenicama. Različita moot court natjecanja najčešće simuliraju suđenje pred najvišim sudovima određene jurisdikcije - npr. iz prava EU-a riječ je o Sudu EU-a kao najvišoj sudskoj instanci u Uniji, ili iz međunarodnog prava o Međunarodnom sudu kao "globalnom sudu".

Tom razlikovanju žalbeni/raspravni sud (appelate/trial court) prilagođen je set vještina koji se nastoji usvojiti dvama formama simuliranog suđenja. U pravilu, kod moot court natjecanja naglasak je primarno na usmenim vještinama i javnom nastupu, a tek zatim na pisanim vještinama i pravnoj argumentaciji. Upravo se zbog toga presude moot courta najčešće odnose na najbolji tim, tj. najbolji nastup, a ne nužno na pravno gledano najjače argumente, te se hipotetski slučaj o kojem se raspravljalo često i ne rješava meritorno. To je jedan od glavnih argumenata suca Kozinskog u kritici moot court natjecanja kao metode pravnog obrazovanja. ${ }^{56}$ Slično tome, Martineau kritizira moot court natjecanje zbog naglašavanja forme umjesto sadržaja, tj. tehnike umjesto merituma. ${ }^{57}$

Sudac Kozinski, dakle, smatra da moot court natjecanje ne razvija odgovarajuće pravničke vještine s obzirom na to da se takva natjecanja osvajaju na temelju generičkih vještina (govor, uvjerljivost, nastup itd.), a ne činjenica hipotetskog

55 Snape i Watt, op. cit. u bilj. 3, 2000., str. 4 - 5; Ringel, L.; Knerr, C., Moot Court: Commitment and Rewards, u: Weizer, P. I. (ur.), How to Please the Court: A Moot Court Handbook, Peter Lang, New York, 2007., str. 1.

56 Sudac Kozinski uspoređuje moot court natjecanje i pravi sud na sljedeći način (op . cit. u bilj. 54, str. 182 - 183, prijevod autora): "Pred stvarnim sudom fokus odvjetnika je na dobivanju slučaja u korist klijenta. Interesi klijenta i odvjetnika se poklapaju; stoga odvjetnik nije zadovoljan ako njegov klijent ne pobijedi. [...] S druge strane, moot court je jako različit: odvjetnik [u simulaciji] nema nikakvog interesa u ishodu slučaja; njegov interes je u cijelosti osobni - dobiti pohvale za svoj nastup. Naravno, iskusni odvjetnici oslanjaju se u pravim slučajevima na svoju dosjetljivost i šarm kako bi pridobili naklonost sudaca. Ali te karakteristike nisu same sebi svrha. Naprotiv, svrha je u dobivanju slučaja u korist klijenta. [...] A ono što je zadatak sudaca na moot courtu jest upravo - ne suditi o meritumu [hipotetske] pravne stvari [tj. o pravnim argumentima], nego o uspješnosti i uvjerljivosti odvjetnika." Vidi i Snape i Watt, op. cit. u bilj. 3, 2000., str. 5 - 6 .

57 Martineau, R. J., Moot Court: Too Much Moot and Not Enough Court, American Bar Association Journal, sv. 67, br. 10, 1981., str. 1295. 
slučaja i pravnih argumenata. ${ }^{58}$ Također, na moot court natjecanju natjecatelji istodobno zauzimaju uloge tužitelja i tuženika. Time se ne posvećuju u potpunosti interesima samo jedne strane u sporu, što je neminovno u stvarnim slučajevima u kojima su interesi odvjetnika i klijenta u pravilu jednaki: ${ }^{59}$ primjerice, oslobađajuća presuda ili maksimalan iznos naknade štete. Studenti se stoga oslanjaju na izbalansirane i "osrednje" argumente, a ne na jednostrane i isključive, kakvi su nužni da bi se sud u sporu pridobio na jednu stranu. ${ }^{60}$ Nadalje, sudac Kozinski iznosi argument u prilog svoje kritike da se "slučajevi rijetko dobivaju [...] u usmenoj fazi [tj. usmenom argumentacijom]". ${ }^{61}$ I zaista, brojke u SAD-u pokazuju minimalnu vjerojatnost za uspjeh žalbenog postupka na usmenom ročištu. ${ }^{62}$ Stoga se (donekle) s pravom propituje svrha pripremanja studenata za usmene nastupe pred sudovima kada oni u praksi, barem u pojedinim jurisdikcijama, nemaju veliku važnost.

\subsection{Odgovor na kritiku}

Elaboriran odgovor na kritiku suca Kozinskog objavljen je u članku Michaela Hernandeza ${ }^{63}$ On u svojem odgovoru nudi protuargumente na kritiku suca Kozinskog te pritom naglašava vještine pisanja, zastupanja, izgradnju osobnosti te brojne druge koristi koje se stječu sudjelovanjem u moot court natjecanju, a obogaćuju životopise studenata te su rezultat upravo usmjeravanja na formu umjesto na sadržaj. ${ }^{64}$ Pritom Kozinski ispušta činjenicu da svrha moot courta nije statična ni određena ciljem, tj. osvajanjem natjecanja, nego zapravo dinamična i određena procesom, tj. stjecanjem iskustva već kroz samo sudjelovanje, na taj način doslovno oživljavajući stari olimpijski ideal o "važnosti sudjelovanja". Istodobno odgovarajući na argument da moot court natjecanje ne predstavlja uvjerljivo posvećivanje interesima jedne od stranaka u postupku zauzimanjem isključive pozicije "za ili protiv" određenog pravnog problema, Hernandez

58 Kozinski, op. cit. u bilj. 54, str. 181.

59 Ibid., str. 182.

60 Ibid.

$61 \quad$ Ibid., str. 186.

62 Finneran, op. cit. u bilj. 36, str. 124. U posljednjih deset godina u SAD-u postotak uspješnih žalbi kretao se između 6,7 \% i 9,3\% u postupcima pred žalbenim sudovima.

63 Hernandez, M. V., In Defense of Moot Court: A Response to "In Praise of Moot Court Not!”, Review of Litigation, sv. 70, br. 1, 1998., str. $69-89$.

Ibid., str. $71-80$. 
naglašava vrijednost upravo takvog stava: pripremajući istodobno optužnicu i obranu studenti se uče zadržavanju profesionalne objektivnosti i emocionalne distanciranosti od klijentove pozicije, čime se čuva objektivnost i nepristranost rasuđivanja i odlučivanja. ${ }^{65} \mathrm{U}$ konačnici, podatak da kod gotovo četvrtine žalbi u SAD-u bude zakazano usmeno ročište (dakle, postupak ne završava na ispitivanju pismenih podnesaka) govori u prilog praktičnoj, osim akademske i pedagoške, vrijednosti moot court natjecanja. ${ }^{66}$ Stoga, čak iako usmeni argumenti na kraju ipak ne dovode do preokreta u konkretnom slučaju ili dotadašnjoj sudskoj praksi, zakazivanje usmenog ročišta implicira (barem) da žalbeno vijeće nije $\mathrm{u}$ potpunosti uvjereno $\mathrm{u}$ pisane navode stranaka $\mathrm{u}$ žalbenom postupku te (barem) dijelom ostavlja mogućnost da bude "uvjereno u suprotno". ${ }^{67}$ Takva važnost usmenog izlaganja pred sudom sažeta je u izjavi suca Vrhovnog suda SAD-a Roberta Jacksona: "Ako se usmeno izlaganje zastupnika pred sudom svodi na čitanje naglas unaprijed pripremljenog pisanog podneska, bolje da je [zastupnik] ostao kući." ${ }^{68}$

Ne osporavajući vrijednost kritike pojedinih nedostataka procesa izvođenja simuliranog suđenja, stav autora je da moot court natjecanje treba nastaviti metodološki unaprjeđivati kroz, primjerice, davanje veće važnosti pisanim podnescima i pravnim argumentima, poboljšanje suđenja i načina ocjenjivanja natjecatelja itd. Mišljenje je autora da činjenica da na moot court natjecanju možda ne pobjeđuje uvijek najbolji pravni tim, kao što sugerira sudac Kozinski, nego najbolje formalno pripremljen tim, ne negira brojne koristi koje studenti stječu već kroz samo sudjelovanje i pripremu za natjecanje. U postojećoj literaturi slično tome gotovo se jednoglasno brane prevladavajuće koristi moot court natjecanja te naglašava potreba unaprjeđenja tog oblika nastave, što se može ostvariti samo kroz "više, a ne manje moot courtova". ${ }^{9}$ Finneran također zaključuje da je važno na fakultetima što više koristiti prednosti iskustva stečenoga na moot

${ }^{65}$ Ibid., str. 74 - 76. Slično i Kritchevsky, B., Judging: The Missing Piece of the Moot Court Puzzle, University of Memphis Law Review, sv. 37, br. 1, 2006., str. 45 - 74.

66 Finneran, op. cit. u bilj. 36, str. 125.

67 Ibid.

68 Jackson, R. H., Advocacy Before the United States Supreme Court, Cornell Law Review, sv. 37, br. 1, 1951., str. 9; vidi i Wice, B., Oral Argument in Criminal Cases: 10 Tips for Winning the Moot Court Round, Texas Bar Journal, sv. 69, 2006., str. 228, navedeno prema Finneran, op. cit. u bilj. 36, str. 129 (bilješke 20 i 21).

69 Hernandez, op. cit. u bilj. 63, str. 89. Slično i: Butler, J.; Mansted, R., The Student as Apprentice: Bridging the Gap Between Education, Skills and Practice, Journal of the Australasian Law Teachers Association, sv. 1, br. 1-2, 2008., str. 294, navedeno prema Yule, McNamara i Thomas, op. cit. u bilj. 23, str. 232. 
court natjecanjima s obzirom na to da je ono za mnoge studente prvi (a ponekad i jedini) kontakt sa zastupanjem pred sudom, posebno uzimajući u obzir "brojne prednosti koje [moot court] ima kao pedagoško sredstvo". ${ }^{70}$ Iznimno je važno i provođenje daljnjih istraživanja o praktičnim vrijednostima moot court natjecanja: o metodama pravnog obrazovanja koje stvaraju dobrog i uvjerljivog pravnika, o usklađenosti tih metoda s profesionalnim izazovima koji studente očekuju u pravničkoj karijeri, o uključenosti pravne prakse u strukturiranje i izvođenje moot court natjecanja u nastavi itd. ${ }^{71}$ Upravo je to posljednje jedan od istraživačkih ciljeva ovog rada, ponajprije u kontekstu nacionalnog pravnog i obrazovnog sustava.

\subsection{Moot court natjecanje u studijskom programu}

Jedan od osnovnih prijepora u literaturi vodi se oko pitanja treba li moot court natjecanje činiti dio obveznih ili izbornih predmeta u sklopu programa pravnog studija ili pak treba ostati izvannastavna aktivnost kojoj studenti pristupaju na dobrovoljnoj osnovi. Određeni trend jest da, u namjeri da se $u$ nastavu uvede što više elemenata aktivnog učenja, profesori na pravnim fakultetima koriste moot court natjecanje kao metodu u različitim predmetima i seminarima koje predaju. Navedeni trend primjetan je i kod pojedinih nastavnika na Pravnom fakultetu $\mathrm{u}$ Zagrebu, koji na vlastitu inicijativu uključuju mini moot court natjecanja $\mathrm{u}$ izvođenje svojih predmeta i seminara. Međutim, neki od argumenata protiv moot courta kao zasebnog obveznog predmeta su: (i) elitizam, u smislu da se kroz moot court studenti pripremaju za elitne društvene pozicije odvjetnika i sudaca viših sudova; (ii) s prethodnim povezana pristranost (ili, zaista, fiksiranost) pravničkog obrazovanja na pravnu praksu u užem smislu te riječi (odvjetništvo i sudstvo), s obzirom na činjenicu da u pojedinim jurisdikcijama u prosjeku manje od pola diplomiranih pravnika kroz karijeru završi u tim zvanjima; (iii) naglašavanje važnosti verbalnih vještina, čime se dovodi u podređen položaj studente kojima engleski (najčešće, jezik najpopularnijih i najrasprostranjenijih međunarodnih moot court natjecanja) nije materinski jezik, kao i studente s poteškoćama sa sluhom i govorom. ${ }^{72} \mathrm{~S}$ druge strane, primjetno je povećanje broja

70 Finneran, op. cit. u bilj. 36, str. 126. Općenito o prednostima moot court natjecanja kao pedagoškog sredstva vidi u: Bergsten, E. E., Experiential Education Through the Vis Moot, Journal of Law \& Commerce, sv. 34, br. 1, 2015., str. 1 - 15, navedeno prema Finneran, op. cit. u bilj. 36, str. 126 (bilješka 16).

71 Finneran, op. cit. u bilj. 36, str. 133.

72 Snape i Watt, op. cit. u bilj. 3, 2000., str. 231. 
fakulteta koji uvode moot court natjecanje kao obvezni dio redovitog studijskog programa, najčešće na razini diplomskog studija. ${ }^{73}$

\subsection{Prednost pri zapošljavanju}

Iako je odavno prepoznat kao iznimno korisno iskustvo, u stvarnosti relativno mali broj studenata sudjeluje u moot court natjecanjima iz više razloga, iako se ta brojka posljednjih godina znatno povećava. Taj manji krug studenata stoga je nakon završetka školovanja istaknut u odnosu na konkurenciju, što je osobito važno danas u stanju zasićenja pravničkog tržišta i hiperinflacije kadrova koji ne uspijevaju pronaći odgovarajući posao u struci. U prilog argumentu da sudjelovanje na moot court natjecanju povećava zapošljivost ide i činjenica da je pravna struka često izravno uključena u takva natjecanja: bilo kroz sudjelovanje u osmišljavanju hipotetskog problema, sudjelovanje u simulaciji u ulozi arbitara, bilo sponzoriranjem takvih natjecanja te dodjeljivanjem nagrada za najuspješnije sudionike (prakse, posjete odvjetničkim uredima i sl.). ${ }^{74}$

Također, za studente koji se namjeravaju baviti istraživačkom i znanstvenom djelatnošću sudjelovanje na moot court natjecanju, osim generičkih vještina o kojima je prije bilo govora, omogućuje i usvajanje znanja u određenoj oblasti koje se zatim može pretvoriti u akademski članak. ${ }^{75}$ Tako su brojni studenti zagrebačkog Pravnog fakulteta radove za koje su nagrađivani dekanovim i rektorovim nagradama, te ih objavljivali u znanstvenim i stručnim časopisima, počinjali istraživati i stvarati upravo u okviru priprema za različita moot court natjecanja. U pogledu većih šansi za zaposlenje generičke vještine stečene na moot court natjecanjima mogu odigrati znatnu ulogu u samom postupku dobivanja posla, primjerice kroz uspješniju prezentaciju na razgovorima za posao. Za uspješno zapošljavanje od presudne važnosti znaju biti i profesionalni kontakti, koji se u velikom broju ostvaruju sudjelovanjem na moot court natjecanjima. To je posebno relevantno za studente koji nastoje izgraditi karijeru u međunarodnom okruženju te im nacionalni fokus nije dostatan za takvo što. Sudjelovanje u međunarodnim moot court natjecanjima tim pravnicima otvara vrata međunarodnog (ili, za Republiku Hrvatsku također iznimno relevantnog, europskog) prava.

\footnotetext{
73 Snape i Watt, op. cit. u bilj. 3, 2010., str. 5.

74 Kee, op. cit. u bilj. 35, str. 106.

75 Ibid., str. 107.
} 


\section{INICIJALNO TESTIRANJE HIPOTEZE}

\subsection{Stavovi poslodavaca općenito}

Slično kao i kod prevladavajućih pozitivnih stavova studenata i profesora o koristima moot court natjecanja za buduću pravničku karijeru, o kojima je bilo govora u dijelu 3.1 ovog rada, mnogi tvrde da poslodavci koji vrednuju takvo iskustvo pri zapošljavanju donose ispravnu odluku. ${ }^{76}$ Razloga je više: osobito, moot court natjecanje je među najvrjednijim iskustvima za studente prava $u$ pogledu profesionalnog razvoja jer ih još za vrijeme studija dovodi u situaciju da pripremaju i izlažu složene pravne argumente o hipotetskom slučaju pred stvarnim sucima i odvjetnicima. ${ }^{77}$ Time studenti već na fakultetu usavršavaju određene vještine, koje se često zanemaruju u klasičnim programima pravnih fakulteta, a ključne su za uspješan nastup odvjetnika pred sudom. ${ }^{78}$

Pojedina odvjetnička društva na svojim stranicama navode da iskustvo moot court natjecanja nije presudno, iako postoji percepcija da kao pripravnike zapošljavaju samo kandidate s takvim iskustvom. ${ }^{79}$ Po nama samo postojanje takve percepcije upućuje na to da i poslodavci / odvjetnička društva u Hrvatskoj i susjednim zemljama zaista daju prednost pri zapošljavanju kandidatima koji imaju iskustvo s moot court natjecanjem. U svakom slučaju, ta pretpostavka bit će raspravljena niže u radu (dio 4.3) na temelju prikupljenih odgovora na upitnik.

Zanimljivo je da odvjetnička praksa pokazuje pozitivan stav prema moot court natjecanju ne samo kao metodi obrazovanja pravnika nego i kao pomagalu odvjetnicima za pripremu nastupa pred sudovima. Pojedini veliki odvjetnički uredi u SAD-u tako redovito organiziraju neformalne interne moot courtove. Njihovi odvjetnici i partneri pritom “igraju” uloge sudskih vijeća pred kojima drugi odvjetnici izlažu pravne argumente u procesu priprema za stvarno suđenje ili u svrhu testiranja određenih pravnih problema (aktualnih ili onih za koje se pretpostavlja da će se uskoro pojaviti u praksi). ${ }^{80}$ Koristi moot court natjecanja

76 Finneran, op. cit. u bilj. 36, str. 121.

77 Ibid

78 Ibid. Finneran također naglašava kao kvalitetu najboljih odvjetnika "izgradnju osobnog stila nastupa pred sudom”, koji se praktično uvježbava kroz moot court natjecanje te se "bruse vještine uvjeravanja stvarnih sudaca". Ibid., str. 127.

79 Karanović \& Nikolić, How to become a Kandidate, https://www.karanovicpartners.com/ wp-content/uploads/2019/02/How_to_become_a_kandidate.pdf (2. prosinca 2017.).

80 Magnuson, E. J., To Moot or not to Moot: What was the Question?, Robins Kaplan LLP, https://www.robinskaplan.com/resources/articles/to-moot-or-not-to-moot-what- 
za pripremu odvjetnika u mogućnosti su prezentiranja starijim i iskusnijim kolegama odvjetnicima argumenata s kojima se planira ići pred više žalbene sudske instance; dobivanju povratnih informacija od njih o snazi i valjanosti određenih argumenata; te prilici za vježbanje nastupa odvjetnika i njihova pristupa aktualnim pravnim problemima. ${ }^{81}$

Taj trend još je prisutan većinom u SAD-u. Ondje je prihvaćeno stajalište da je moot court "neizostavan dio priprema za izlaganje pred Vrhovnim sudom, zbog činjenice da razrađuje nijanse i unaprjeđuje snagu pravnih argumenata" ${ }^{82}$ Nešto slično, međutim, u Europi još uvijek nije slučaj. Jedan od razloga je svakako i kontinentalnopravna tradicija, u kojoj je sudski postupak drukčije uređen, s većim naglaskom na pisanom nego na usmenom dijelu postupka pred sudovima. Svejedno, pretpostavlja se da će u budućnosti u sve više država moot court natjecanje biti korišteno na sličan način: umirovljeni suci i iskusni odvjetnici formirat će sudska vijeća koja će slušati odvjetnike koji pripremaju svoje izlaganje pred višim sudovima, čak i u pravim slučajevima koji su u fazi pripreme za suđenje (poštujući u potonjem slučaju etičke standarde profesije i povjerljivost odnosa odvjetnik - klijent). ${ }^{83}$ Snape i Watt ovako zamišljaju jednu od potencijalnih budućih funkcija moot courta:

“Pravo je prepuno slučajeva koji nisu riješeni i presuđeni. Problemi povezani s tim slučajevima ostaju hipotetski [moot] sve dok ih se ne iznese pred sud. Zbog financijskih troškova [među ostalim] vođenja sudskih postupaka mnogo pravnih problema ostaje neriješeno unatoč interesu javnosti da se pojedine neodređenosti [pravne praznine ili sporne norme] prava razjasne i autoritativno razriješe. Drugim riječima, 'pravna istina je tu, čekajući da bude potvrđena'. Moot court može se primijeniti u ovakvim situacijama. Moot vijeće sastavljeno od umirovljenih sudaca i redovitih profesora prava slušalo bi takve hipotetske slučajeve i donosilo odluke koje se objavljuju. Kao što se sve više sudova u svojim presudama poziva na akademske tekstove i rezultate znanstvenih istraživanja, redoviti suci bi se mogli u rješavanju stvarnih sporova referirati i na uvjerljivost i argumentaciju takvih [razumnih] moot presuda." 84

was-the-question (7. studenoga 2017.). Odvjetnički uredi koji organiziraju interne moot courtove te usluge pružaju pro bono ili ih čak naplaćuju.

Ibid.

82 Snape i Watt, op. cit. u bilj. 3, 2000., str. 234.

83 Ibid.

84 Ibid., str. $234-235$ (prijevod autora). 
Iako se takva mogućnost u ovom trenutku zaista čini hipotetskom (moot) i malo vjerojatnom, pogotovo iz perspektive pravne kulture države poput Republike Hrvatske, postoje određene naznake da se korištenje moot court natjecanja zaista polako razvija u tom smjeru.

\subsection{Moot court u Zagrebu}

Prije prelaska na raspravu o rezultatima našeg kratkog istraživanja dat ćemo nekoliko napomena o moot court natjecanjima koja se odvijaju na Pravnom fakultetu Sveučilišta u Zagrebu, a u fokusu su našeg upitnika.

Među podacima o instituciji dostupnim na internetskim stranicama Pravni fakultet $\mathrm{u}$ Zagrebu navodi da u izvođenju nastave "primjenjuje suvremene tehnike podučavanja" te je stoga "uveo niz inovativnih oblika nastave", među ostalima i simulirana suđenja (moot courts). ${ }^{85}$ Također se spominje da zagrebački Pravni fakultet prepoznaje "simulirana suđenja (moot courts) kao jednu od najkvalitetnijih metoda izobrazbe budućih pravnika, snažno podupire ovaj oblik učenja te omogućava svojim studentima sudjelovanje na više od deset natjecanja u simuliranom suđenju u inozemstvu" ${ }^{86}$ Pravilima o studijskom programu propisano je da "u okviru moot court natjecanja, studenti prolaze višemjesečne pripreme koje vode nastavnici Fakulteta i stručnjaci iz prakse, tijekom kojih usavršavaju vještine pravnog istraživanja, pisanja i usmene argumentacije". ${ }^{87}$ Studenti Pravnog fakulteta sudjeluju na niže navedenim natjecanjima koja se u najvećem broju slučajeva održavaju na engleskom jeziku, u konkurenciji najprestižnijih svjetskih sveučilišta. Konačno, informacije na internetskim stranicama fakulteta zaključuju da su "u pravnoj praksi vještine stečene na simuliranim suđenjima prepoznate kao jedan od ključnih faktora pri zapošljavanju mladih pravnika". 88

Moot court natjecanja na kojima sudjeluju studentski timovi zagrebačkog Pravnog fakulteta, a o kojima smo u upitniku ispitali odvjetnička društva i urede s područja grada Zagreba, jesu: ${ }^{89}$

85 Usp. https://www.pravo.unizg.hr/images/50000869/Letak\%20pravo\%202016.pdf (12. travnja 2019.).

86 Usp. https://www.pravo.unizg.hr/studij/integrirani-pravni/moot_court i https://www. pravo.unizg.hr/_download/repository/Pravilnik_o_studiju.pdf (12. travnja 2019.).

87 Ibid.

88 Ibid.

89 Usp. https://www.pravo.unizg.hr/studenti/moot_courts (12. studenoga 2017.). 
1) Regional Moot Court Competition before European Court of Human Rights ${ }^{90}$ i European Human Rights Moot Court Competition ${ }^{91}$, regionalno i kontinentalno natjecanje koja se sadržajno bave katalogom prava iz Europske konvencije o ljudskim pravima te simuliraju suđenje pred Sudom za ljudska prava u Strasbourgu

2) Central and Eastern European Moot Competition ${ }^{92}$ i European Law Moot Court ${ }^{93}$, regionalno i svjetsko natjecanje iz oblasti prava EU-a na kojima se simulira suđenje pred Sudom EU-a u Luxembourgu

3) International Criminal Court Moot Court Competition ${ }^{94}$, simulacija suđenja o međunarodnom kaznenom pravu koja se usmjerava na proceduralne i supstantivne aspekte Rimskog statuta i ostale izvore međunarodnog kaznenog prava

4) Law Academy - Liaison Project ${ }^{95}$, simulacija rada u korporativnom okruženju gdje studenti simuliraju uloge in-house pravnika velikih kompanija (vrijedi napomenuti da se ta metoda razlikuje od klasičnih moot court natjecanja koja simuliraju postupak pred određenim sudom)

5) Moot Court Croatia ${ }^{96}$, državno natjecanje u simuliranom suđenju s hipotetskim problemom koji obuhvaća različita područja nacionalnog pravnog sustava

6) Philip C. Jessup International Law Moot Court Competition ${ }^{97}$, simulacija suđenja pred Međunarodnim sudom s hipotetskim predmetom koji se dotiče različitih područja međunarodnog prava (međunarodno kazneno pravo, međunarodno pravo interneta, međunarodno pravo mora, međunarodno trgovačko pravo)

7) Price Media Law Moot Court ${ }^{98}$, svjetsko natjecanje usmjereno na probleme koji se dotiču slobode govora, uloge i regulacije medija i modernih informacijskih i komunikacijskih tehnologija

90 Usp. https://www.facebook.com/RegionalMootCourtCompetition/ (14. studenoga 2017.).

91 Usp. https://ehrmcc.elsa.org/ (14. studenoga 2017.).

92 Usp. http://www.ceemc.co.uk/ (14. studenoga 2017.).

93 Usp. http://europeanlawmootcourt.eu/ (14. studenoga 2017.).

94 Usp. http://iccmoot.com/ (14. studenoga 2017.).

95 Usp. http://law-academy.eu/ (14. studenoga 2017.).

96 Usp. https://www.estudent.hr/category/natjecanja/moot-court-croatia/ (14. studenoga 2017.).

97 Usp. https://www.ilsa.org (14. studenoga 2017.).

98 Usp. http://pricemootcourt.socleg.ox.ac.uk/ (14. studenoga 2017.). 
8) Willem C. Vis International Arbitration Commercial Moot ${ }^{99}$, natjecanje iz međunarodne trgovačke arbitraže koje se temelji na UN-ovoj Konvenciji o ugovorima o međunarodnoj trgovini robe (UNCISG), Konvenciji iz New Yorka o priznanju i ovrsi stranih arbitražnih odluka te Model zakonu o međunarodnoj trgovačkoj arbitraži UNCITRAL-a (Komisije UN-a za međunarodno trgovačko pravo).

\subsection{Rezultati kratkog istraživanja}

Od 133 odvjetnička društva/ureda kojima je upitnik poslan dobili smo ukupno 48 odgovora $^{100}$, što čini stopu odgovora od $36 \%$.

Većina ispitanika ima znatno iskustvo rada u odvjetništvu (45 \% njih više od 10 godina, $17 \%$ od 5 do 10 godina iskustva). Gotovo svi (98 \%) rade u odvjetničkim društvima.

Velika većina ispitanika (88 \%) upoznata je s moot court natjecanjima na kojima sudjeluju studenti Pravnog fakulteta u Zagrebu. Dio ispitanika također ima iskustvo sudjelovanja na moot court natjecanjima (44\%), a samo manji broj njih (29\%) prethodno je financijski podržao studente u sudjelovanju na nekom moot court natjecanju.

Znatna većina ispitanika (69 \%) sudjeluje u procesu zapošljavanja u svojem odvjetničkom društvu kroz, primjerice, ocjenjivanje zaprimljenih pisanih prijava, ocjenjivanje pristiglih životopisa, sudjelovanje na intervjuu s kandidatima itd. To znači da velik broj anketiranih osoba izravno sudjeluje u donošenju odluka o zapošljavanju te da njihovo mišljenje iskazano u preostalim odgovorima na upitnik o prednostima moot court natjecanja ima ulogu u tom procesu. Pritom velika većina (79 \%) smatra da kandidati s iskustvom sudjelovanja u moot court natjecanjima imaju prednost pred ostalim kandidatima pri zapošljavanju, kao i to da praktični oblici nastave kao što je moot court natjecanje općenito doprinose studentima u budućem bavljenju odvjetničkom profesijom (90 \%).

U pogledu konkretnih moot court natjecanja na kojima sudjeluju studentski timovi zagrebačkog Pravnog fakulteta, ispitanici su posebno istaknuli Willem C. Vis International Arbitration Commercial Moot (46\%), natjecanje koje se bavi problemom međunarodne trgovačke arbitraže. Određeni dio ispitanika istaknuo

99 Usp. https://vismoot.pace.edu/ (14. studenoga 2017.).

100 Navedena brojka ne odgovara nužno ukupnom broju odvjetničkih društava koja su odgovorili na upitnik jer postoji mogućnost, kako je bilo navedeno u uvodu rada, da je iz jednog odvjetničkog društva više osoba odgovorilo na upitnik, što nije moguće provjeriti s obzirom na to da su upitnici anonimni. 
je Moot Court Croatia (17 \%), natjecanje koje se bavi različitim problemima pravnog sustava Republike Hrvatske. Tematski, $17 \%$ ispitanika istaknulo je pravo Europske unije, uzimajući u obzir zajedno dva moot court natjecanja koja se bave tom tematikom.

Upitani o razlozima zbog kojih posebno ističu prethodno navedena moot court natjecanja ispitanici su u velikom broju navodili materiju/sadržaj samog natjecanja (67 \%), tj. pravno područje na koje se natjecanje usmjerava. Znatan broj ispitanika (52\%) naveo je pisanu i usmenu pravnu argumentaciju koja se usavršava sudjelovanjem na navedenim natjecanjima. $36 \%$ ispitanika navelo je metode razumijevanja i interpretacije pravnih normi koje su svojstvene pravnom području kojim se određeno natjecanje bavi, a $32 \%$ komercijalnu iskoristivost tog pravnog područja u praksi.

Upitani za mišljenje o vještinama koje su važne za uspješan rad u odvjetništvu ispitanici su u znatnom broju kao prilično ili iznimno važne isticali govorničke vještine i vještine javnog nastupa (81 \%), timski rad (85 \%), vještine pisanja podnesaka (87\%), spremnost za učenje (96\%), kao i upornost i posvećenost radu (98\%). Gotovo sve navedene vještine su, kako smo prethodno vidjeli, navođene u literaturi kao koristi koje se ostvaruju sudjelovanjem u moot court natjecanjima. S druge strane, velika većina ispitanika (67 \%) za uspješan rad u odvjetništvu za studente malo ili neznatno važnim smatra poznavanje važeće legislative u pojedinim područjima prava. Smatramo da je upravo fokus većine predmeta koji se izvode na Pravnom fakultetu u Zagrebu usmjeren na memoriranje i reprodukciju važeće legislative u pojedinim područjima prava, što se, kako vidimo, od strane odvjetnika smatra manje važnim u praksi. Ovime se potvrđuju brojni navodi da pravni fakulteti ne pripremaju adekvatno studente za rad u praksi, zanemarivanjem razvoja generičkih vještina, a pretjeranim fokusom na poznavanje legislative, koja se često mijenja i koju nije nužno potrebno poznavati napamet koliko uspješno pretraživati i po potrebi konzultirati.

Od drugih vještina/kvaliteta, koje nisu bile ponuđene u upitniku, a ispitanici su ih ocijenili iznimno važnima za rad u odvjetničkom uredu, ističu se odgovornost, organiziranost, snalažljivost, samopouzdanje, ambicioznost, energičnost, komunikativnost, preciznost i savjesnost, lojalnost, ljubaznost, vještine prilagođavanja, prodajne vještine i vještine pronalaska klijenata, kritičko razmišljanje i logičko zaključivanje, te istraživanje sudske prakse i drugih izvora prava. Dakle, niz generičkih vještina koje smo prethodno naveli kao koristi koje se ostvaruju sudjelovanjem u moot court natjecanjima.

Konačno, velika većina ispitanika (75 \%) iskazala je interes podržati ili uključiti se u oblik izvođenja praktične nastave kao što je moot court natjecanje na Pravnom fakultetu u Zagrebu. Najveći broj njih spreman je sudjelovati u 
sudačkim panelima na moot court natjecanjima (75\%) te predavati studentima o radu u odvjetničkoj praksi, tj. iskustvu zastupanja pred sudovima (67 \%), dok bi manji broj ispitanika bio spreman financirati odlaske studenata na moot court natjecanja (31 \%) ili financirati organizaciju tih natjecanja (14\%). Također, dio ispitanika naglasio je spremnost uključiti se u izvođenje moot court natjecanja putem mentoriranja studentskih timova zagrebačkog pravnog fakulteta.

\section{ZAKLJUČCI}

U ovom radu pokušali smo izložiti teorijsku raspravu o prednostima i nedostacima simulacija suđenja kao nastavne metode te u konačnici doznati odgovor na pitanje prepoznaje li odvjetnička praksa vrijednost simulacija suđenja (moot court natjecanja) kao oblika izvođenja nastave, odnosno smatraju li poslodavci (odvjetnička društva i uredi) iskustvo sudjelovanja u moot court natjecanjima poželjnim, tj. prednošću pri zapošljavanju. Zaključak na temelju prethodno prikazanih podataka sugerira pozitivan odgovor na to pitanje, iako je (kako navodimo u uvodnom dijelu rada) za konačnu potvrdu te teze potrebno provesti daljnja opsežna istraživanja. Međutim, smatramo da svejedno vrijedi navesti inicijalna zapažanja do kojih smo došli na temelju provjere stavova poslodavaca.

Konkretno, ispostavlja se da velika većina ispitanika smatra da moot court natjecanja kao praktični oblik nastave u mnogome doprinose studentima $\mathrm{u}$ budućem bavljenju odvjetničkom profesijom te da stoga poslodavci pri zapošljavanju daju prednost kandidatima s takvim iskustvom. Poslodavci posebno cijene koristi moot court natjecanja kao oblika nastave u pogledu usavršavanja pisane i usmene pravne argumentacije studenata, kao i metoda razumijevanja i interpretacije pravnih normi koje se stječu sudjelovanjem na moot court natjecanjima. Pritom također ističu, kao iznimno važne za rad u odvjetničkom uredu, niz drugih generičkih vještina koje su u literaturi prepoznate kao vještine koje se na najbolji način upravo stječu na moot court natjecanjima.

Također, istraživanje pokazuje da odvjetnici smatraju najpoželjnijim iskustvo sudjelovanja na moot court natjecanjima koja se bave specifičnom materijom, trenutačno praktično i komercijalno najiskoristivijom u odvjetničkom poslu, kao što je natjecanje iz međunarodne trgovačke arbitraže.

S druge strane, velika većina ispitanika malo ili neznatno važnim za uspješan rad u odvjetništvu smatra poznavanje (tj. sposobnost memoriranja i reprodukcije) važeće legislative $u$ pojedinim područjima prava, što je tradicionalno u najvećem fokusu programa domaćih pravnih fakulteta, te metodološkog pristupa predmeta koji se na njima izvode. Smatramo iznimno važnom za kvalitetu obrazovanja i pravničke profesije usklađenost pravnog obrazovanja s preporukama i potreba- 
ma pravne prakse. Navedeno je posebno važno u periodu u kojem se sve manji broj studenata odlučuje upisati pravne fakultete u Republici Hrvatskoj zbog zasićenosti tržišta, nedostatka reforme studijskih programa pravnih fakulteta ili trendova koji favoriziraju tzv. STEM fakultete. Stoga je preporuka autora, formirana na temelju provedenog inicijalnog istraživanja, da se programi pravnih fakulteta u Republici Hrvatskoj orijentiraju na razvoj generičkih vještina koje su prepoznate kao ključne za rad u praksi, među ostalim većim korištenjem moot court natjecanja kao nastavne metode te snažnijom logističkom i nastavnom podrškom postojećim moot court natjecanjima. Što se tiče konkretno Pravnog fakulteta u Zagrebu, prvi korak u tom smjeru mogao bi biti priznavanje moot court natjecanja kao izbornih predmeta u sklopu pete godine programa pravnog studija. ${ }^{101}$ Istodobno, izvođenje drugih obveznih predmeta moglo bi se nadopuniti organiziranjem mini moot court natjecanja na kojima bi u sudačkim panelima sjedili odvjetnici koji su za to u našem istraživanju iskazali velik interes, a u sklopu predavanja koja prethode tim natjecanjima također bi podučavali studente o vještinama zastupanja pred sudovima.

Naš konačan cilj konkretno bi bio povećanje korištenja moot court natjecanja kao nastavne metode na pravnim fakultetima u Republici Hrvatskoj te općenito iniciranje sveobuhvatnog akademskog dijaloga o korištenju praktičnih metoda nastave u pravničkom obrazovanju, u svrhu postizanja modernijeg, učinkovitijeg i pravednijeg pravnog i obrazovnog sustava. Stoga se nadamo da će ovo istraživanje biti prvi korak k otvaranju ove rasprave, barem što se tiče Pravnog fakulteta u Zagrebu.

\section{ANEKS}

a) Podaci o anketnom upitniku

Anketnim upitnikom tražili su se odgovori na sljedeća pitanja:

- Iskustvo rada u odvjetništvu ( $r a d$ u samostalnom/zajedničkom uredu ili društvu, godine iskustva). Kategorija pitanja: zatvoreni tip, ponuđeni višestruki odgovori, međusobno isključivi

- Poznavanje moot court natjecanja (iskustvo sudjelovanja u bilo kojoj ulozi, prethodna financijska podrška). Kategorija pitanja: zatvoreni tip, ponuđeni odgovori da/ne

101 Trenutačno, za sudjelovanje na moot court natjecanjima studentima Pravnog fakulteta u Zagrebu dodjeljuje se 10 ECTS bodova, koji se priznaju u svrhu ispunjenja obveza praktične nastave (u koju još spadaju i praktične vježbe, pravna klinika i terenska praksa), ali ne i kao izborni predmeti pete godine. 
- Sudjelovanje u procesu zapošljavanja (ocjenjivanje pisanih prijava, životopisa, sudjelovanje na intervjuima, mišljenje o prednostima kandidata s moot court iskustvom pred ostalim kandidatima, općenito mišljenje o koristima praktičnih oblika nastave za bavljenje odvjetničkom profesijom). Kategorija pitanja: zatvoreni tip, ponuđeni odgovori da/ne

- Mišljenje o konkretnim moot court natjecanjima (navođenje jednog moot court natjecanja kao najboljeg, razlozi za navedeno moot court natjecanje). Kategorija pitanja: zatvoreni tip, ponuđeni višestruki odgovori, međusobno isključivi za prvu varijablu, moguć odabir više odgovora za drugu varijablu

- Mišljenje o važnosti određenih vještina za uspješan rad u odvjetničkom uredu (govorničke vještine / javni nastup, vještine pisanja podnesaka, timski rad, upornost i posvećenost radu, spremnost za učenje, poznavanje važeće legislative u pojedinim područjima prava). Kategorija pitanja: zatvoreni tip, ordinalne varijable rangirane po intenzitetu, od negativnog dijela skale (1) "nimalo važno" do pozitivnog dijela skale (5) “iznimno važno”

- Zainteresiranost za podršku / uključivanje u izvođenje moot court natjecanja. Kategorija pitanja: mješovita, otvoreni tip (slobodan unos), zatvoreni tip (ponuđeni odgovori da/ne, ponuđeni višestruki odgovori, moguć odabir više odgovora).

Potpun primjerak upitnika može se dobiti kontaktiranjem autora na gore navedene adrese elektroničke pošte.

b) Popis 133 odvjetnička društva i ureda kojima je putem elektroničke pošte poslan upitnik nasumičnim odabirom iz Imenika odvjetnika Hrvatske odvjetničke komore: ${ }^{102}$

Odvjetničko društvo Babić \& Čibarić d.o.o.

Golubić i Partneri j.t.d.

Odvjetničko društvo Balatinec \& Nikolić d.o.o.

Odvjetničko društvo Hanžeković \& Partneri

Odvjetničko društvo Galetović i Galetović

Porobija \& Porobija odvjetničko društvo

Odvjetničko društvo Bogdanović, Dolički \& Partneri

Odvjetnički ured Nino Reskušić

102 Podaci izlistani prema: Hrvatska odvjetnička komora, Imenik odvjetnika, http://www. hok-cba.hr/hr/imenik (5. veljače 2018.). 
Travaš i partneri d.o.o. odvjetničko društvo

Liszt \& Posavec d.o.o.

Žurić i Partneri d.o.o. odvjetničko društvo

Terešak \& Partneri d.o.o.

Odvjetničko društvo Tus Novokmet Smrček d.o.o.

Odvjetnički ured Ranko Pelicarić i Goran Smerdel

Odvjetnički ured Ivan Surjan

Stančić-Rokotov, Šumanović i partneri d.o.o. odvjetničko društvo

Odvjetničko društvo Hondl, Konić, Šimunović, Batur i partneri

Suić \& Škunca d.o.o.

Odvjetničko društvo Grgić i partneri d.o.o.

Tomić \& Klišanin \& Partneri d.o.o.

Divjak, Topić, Bahtijarević Odvjetničko društvo

Mamić, Perić, Reberski i Rimac Odvjetničko društvo d.o.o.

Odvjetničko društvo Bradvica Marić Wahl Cesarec d.o.o.

Odvjetničko društvo Madirazza i Partneri

Mandarić \& Einwalter j.t.d.

Smolek \& Škrinjar d.o.o.

Stefanović \& Vrdelja odvjetničko društvo

Odvjetničko društvo Leko i Partneri d.o.o.

Odvjetničko društvo Šavorić \& Partneri

Kovačević Prpić Simeunović d.o.o.

Mađarić \& Lui odvjetničko društvo d.o.o

Odvjetničko društvo Vukić, Jelušić, Šulina, Stanković, Jurcan \& Jabuka

Odvjetničko društvo Mikuličić, Lončarić, Bahun, Topić

Odvjetničko društvo Bardek, Lisac, Mušec, Skoko d.o.o.

Odvjetničko društvo Kallay \& Partneri d.o.o.

Kunstek, Halle \& Šimac j.t.d.

Škrobot i Partneri d.o.o.

Maržić i partneri odvjetničko društvo j.t.d.

Špehar \& Špehar odvjetničko društvo

Laktić \& partneri odvjetničko društvo d.o.o.

Jelavić \& partneri j.t.d.

Wolf Theiss Croatia 
Odvjetničko društvo Jelić, Čavlina Zrinšćak i Sardelić d.o.o.

Karanović \& Nikolić

Odvjetničko društvo Kapor i partneri d.o.o.

Šeparović, Špehar i Gavranić j.t.d.

Kardum i Partneri j.t.d.

Odvjetničko društvo Čačić \& Partneri j.t.d.

Matijević, Jakirčević i Malkoč d.o.o.

Hrabar \& Partneri d.o.o.

Odvjetničko društvo Žurić i partneri

Owens i Houška odvjetničko društvo j.t.d.

Šakić \& Partneri d.o.o.

Odruštvo Gjanković i Partneri

Odvjetničko društvo Borić i Toš d.o.o

Odvjetničko društvo Glinska i Mišković d.o.o.

Mesić, Potočnjak \& Šušnjar d.o.o.

Budimir \& Meter d.o.o.

Ilić, Orehovec \& Partneri d.o.o.

Odvjetničko društvo Lovrić \& Klobučar j.t.d.

Odvjetničko društvo Smolčić i partneri d.o.o.

Pehnec, Vidović Pehnec j.t.d.

Odvjetničko društvo Borić \& partneri d.o.o.

Matana \& Partneri d.o.o.

Abel \& Grenac \& Ležaić d.o.o. odvjetničko društvo

Arlović \& Kukilo d.o.o.

Planinić, Šoljić i Partneri d.o.o.

Odvjetničko društvo Tušak Miletić i Partneri j.t.d.

Salopek \& Salopek j.t.d.

Palatinuš i Partneri d.o.o.

Ravlić \& Šurjak d.o.o.

Hraste \& Partneri odvjetničko društvo

Jagar \& Grebenar odvjetničko društvo

Božić, Ilić, Žaja i Partneri d.o.o.

Odvjetničko društvo Šunić i partneri j.t.d.

Grubišić \& Lović \& Lalić d.o.o. odvjetničko društvo 
Lozo \& Partneri d.o.o.

Odvjetničko društvo Grahovac, Horvat, Žaper d.o.o.

Odvjetničko društvo Porobija i Špoljarić d.o.o.

Župić \& partneri d.o.o.

Gajski, Grlić, Prka i Partneri d.o.o.

Mamić Grgić Vinter d.o.o.

Zajednički odvjetnički ured Goran Veljović Siniša Borštner, Denis Jelenković, Merima Ibrahimović, Andrej Stanič, Ivana Bilić Komparić, Milena Veljović, Vladimir Veljović i Alan Alagić

Odvjetničko društvo Benko i Partneri d.o.o.

Odvjetničko društvo Cvitković \& Devidé d.o.o.

Korper \& Partneri odvjetničko društvo

Uskoković \& Partneri d.o.o.

Odvjetnik Boris Anišić

Babić i partneri odvjetničko društvo d.o.o.

Odvjetničko društvo Škarica i partneri, Petres i Cvirn d.o.o.

Odvjetničko društvo Zec i partneri d.o.o.

Vidmar i Partneri j.t.d., Ruždjak i partneri j.t.d.

Marković i partneri d.o.o.

Odvjetničko društvo Vlahov Buhin i Šourek d.o.o.

Zajednički odvjetnički ured Dražan Crnković i Alen Pešušić

Kožul i Petrinović odvjetničko društvo d.o.o.

Odvjetničko društvo Vlahov Buhin i Šourek d.o.o.

Odvjetničko društvo Andreis i Partneri d.o.o.

Gjurašić, Fak \& Partneri d.o.o.

Odvjetnik Zoran Tomić

Odvjetničko društvo Buterin \& Posavec

Glamuzina \& Grošeta d.o.o.

Zajednički odvjetnički ured Veljko Knežević, Edi Bradamante, Mira Hinić

Muslim, Ivana Radić, Bojana Pavković, Senka Perhat Smiljanić i Neven

Knežević

Grubeša i Partneri d.o.o.

Šooš Maceljski, Mandić, Stanić \& Partneri d.o.o.

Odvjetničko društvo Kovačević, Koren i partneri d.o.o. 
Odvjetničko društvo Željka Velić-Dvoršćak \& Silvije Skerlev i partneri j.t.d.

Zorić \& Bahat d.o.o.

Mačešić i partneri d.o.o.

Saucha \& Partneri d.o.o.

Par \& Gradac j.t.d.

Marić, Drugović \& Sekovanić d.o.o.

Kačić i Brbora odvjetničko društvo

Jelić, Vuković \& Handžiski odvjetničko društvo

Odvjetničko društvo Anić i partneri

Odvjetnički ured Senka Balog

Odvjetničko društvo Mateša \& Kapitan d.o.o.

Miličević i Šupuković d.o.o.

Odvjetničko društvo Markač-Greif \& Partneri j.t.d.

Rački i kolege j.t.d.

Odvjetnički ured Albina Dlačić

Odvjetničko društvo Antolić i suradnici

Odvjetničko društvo Krsnik i Partneri d.o.o.

Odvjetničko društvo Vukina \& Partneri d.o.o.

Matić, Feldman \& Herman j.t.d.

Odvjetničko društvo Đerek i Partneri j.t.d.

Orešković, Vrtarić \& Partneri d.o.o.

Gugić \& Kovačić d.o.o.

Odvjetničko društvo Bekina, Škurla, Durmiš i Spajić d.o.o.

Odvjetničko društvo Krajinović i Partneri d.o.o.

Marohnić, Tomek \& Gjoić d.o.o.

Ostermann i Partneri d.o.o.

Odvjetničko društvo Batarelo Dvojković Vuchetich d.o.o. 


\section{LITERATURA}

Alemanno, A.; Khadar, L., Reinventing Legal Education. How Clinical Education Is Reforming the Teaching and Practice of Law, Cambridge University Press, Cambridge, 2018.

Carlson, J. L.; Skaggs, N. T., Learning by Trial and Error: A Case for Moot Courts, Journal of Economic Education, sv. 31, br. 2, 2000., str. 145 - 155, https:// doi.org/10.2307/1183186

Ćapeta, T., Courts, Legal Culture and EU Enlargement, Croatian Yearbook of European Law and Policy, sv. 1, 2005., str. 23 - 53, https://doi.org/10.3935/ cyelp.01.2005.02

Daly, Y. M.; Higgins, N., The Place and Efficacy of Simulations in Legal Education: A Preliminary Examination, AISHE-J: The All Ireland Journal of Teaching and Learning in Higher Education, sv. 3, br. 2, 2011., str. 58.1 - 58.20

Finneran, R. E., Wherefore Moot Court?, Washington University Journal of Law \& Policy, sv. 53, 2017., str. 121 - 134

Gygar, T.; Cassimatis, A., Mooting Manual, Butterworths, Sydney, 1997.

Hernandez, M. V., In Defense of Moot Court: A Response to "In Praise of Moot Court - Not!", Review of Litigation, sv. 70, br. 1, 1998., str. 69 - 89

Jackson, R. H., Advocacy Before the United States Supreme Court, Cornell Law Review, sv. 37, br. 1, 1951., str. 1 - 16

Kammerer, E. F., Undergraduate Moot Court: Student Expectations and Perspectives, PS: Political Science and Politics, sv. 51, br. 1, 2018., str. 190 - 193, https:// doi.org/10.1017/S1049096517001925

Kee, C., A Guide to Mooting. The Art of Argument, Cambridge University Press, Cambridge, 2006.

Knerr, C.; Sommerman, A., Undergraduate Moot Court in American Colleges and Universities, Annual General Meeting of the National Communications Association, Seattle, WA (8-12 November 2000), https://eric.ed.gov/?id=ED449747 (24. listopada 2017.).

Kozinski, A., In Praise of Moot Court - Not!, Columbia Law Review, sv. 97, br. 1, 1997., str. 178 - 197, https://doi.org/10.2307/1123450

Kritchevsky, B., Judging: The Missing Piece of the Moot Court Puzzle, University of Memphis Law Review, sv. 37, br. 1, 2006., str. 45 - 74

Lynch, A., Packing Them in the Aisles: Making Use of Moots as Part of Course Delivery, Legal Education Review, sv. 10, br. 1, 1999., str. 83 - 106 
Magnuson, E. J., To Moot or not to Moot: What was the Question?, Robins Kaplan LLP, https://www.robinskaplan.com/resources/articles/to-moot-or-not-tomoot-what-was-the-question (7. studenoga 2017.)

Martineau, R. J., Moot Court: Too Much Moot and Not Enough Court, American Bar Association Journal, sv. 67, br. 10, 1981., str. 1294 - 1297

Pope, D.; Hill, D., Mooting and Advocacy Skills (3rd Edition), Sweet \& Maxwell, London, 2015.

Ringel, L.; Knerr, C., Moot Court: Commitment and Rewards, u: Weizer, P. I. (ur.), How to Please the Court: A Moot Court Handbook, Peter Lang, New York, 2007., str. $1-10$

Rodin, S., Discourse and Authority in European and Post-Communist Legal Culture, Croatian Yearbook of European Law and Policy, sv. 1, 2005., str. 1 - 22, https://doi.org/10.3935/cyelp.01.2005.01

Snape, J.; Watt, G., How to Moot - A Student Guide to Mooting (2nd Edition), Oxford University Press, Oxford, 2010.

Snape, J.; Watt, G., The Cavendish Guide To Mooting (2nd Edition), Cavendish Publishing, London/Sydney, 2000.

Uzelac, A., Survival of the Third Legal Tradition?, Supreme Court Law Review, sv. 49, 2010., str. 377 - 396

Yule, J. M.; McNamara, J.; Thomas, M. N., Virtual mooting: using technology to enhance the mooting experience, Journal of the Australasian Law Teachers Association, sv. 2, br. 1-2, 2009., str. $231-243$ 


\section{Summary}

\section{Antonija Ivančan * \\ Davor Petrić**}

\section{MOOT COURT AS A METHOD OF PRACTICAL EDUCATION AT LAW SCHOOLS}

Moot court is simulation of adjudication before arbitral, national or international courts, and is nowadays increasingly used as a teaching method at law schools. In this article, we first assess the main theoretical and practical elements of moot court as a teaching method. This is followed by a short, introductory empirical verification of the following research question: Does the moot court experience bring advantages for later practice to students, i.e. do, and in what way, students benefit from investing time and effort in moot court during their studies? This article also represents the first attempt of a structured academic discussion in the region about the nature and use of moot court as an educational method. Therefore, our additional goal is to initiate a wider academic dialogue on the use of this method in legal education, as well as to consider the developments in legal practice in drafting recommendations for the reform and enhancement of study programs of law schools, especially in relation to methods of practical education. After the introductory part, the article first outlines the historical development of moot court as an educational method. Then, in the main part, we offer a systematization of the current findings from literature and address specific benefits and shortcomings of moot court. In the final part of the article, we present and discuss the initial results of a brief questionnaire that was sent to law firms in Zagreb. The final section concludes with reflections on our theoretical discussion and research outcomes.

Keywords: moot court, practical education, law school, benefits and shortcomings, law firms

* Antonija Ivančan, mag. iur, LL.M., Assistant Lecturer, Faculty of Law, University of Zagreb, Trg Republike Hrvatske 14, Zagreb; aivancan@pravo.hr;

ORCID ID: orcid.org/0000-0001-7192-2449

** Davor Petrić, mag. iur., Assistant Lecturer, Faculty of Law, University of Zagreb, Trg Republike Hrvatske 14, Zagreb; dpetric@pravo.hr;

ORCID ID: orcid.org/0000-0001-7737-2150 